\title{
MANAGEMENT OF AND POTENTIAL RETURN ON PRIVATE INVESTMENTS IN LATVIAN SPORTS
}

\author{
Mārtiṇš Lauva \\ Ventspils University, Ventspils, Latvia \\ Uldis Grāvītis \\ Latvian Academy of Sport Education, Riga, Latvia
}

\begin{abstract}
Latvian sports authorities under the Ministry of Education and Science are the main organisers of the sports life in Latvia. However, they have not been successful in providing equally good support to all athletes who need it. It is especially difficult to receive support for improving skills of individual athletes engaged in team sports. Often it is the individual mastery of an athlete that prohibits them from moving on to the adult level of sports of high achievement, even if the athlete was very talented and one of the best in the country, when he/she was young. The descriptive statistical method and content analysis were used to assess shortcomings in the allocation of finances in the Latvian sports industry. The study demonstrated that a successful process of private investments ensures a positive return on the investments, as well as the development of athletes. One way to build successful cooperation is by creating high-quality sports development centres or sports investment management companies, which will efficiently contribute to the athletes' transition from youth to professional sports. The efficiency of the methodology developed can be demonstrated by creating a company, which would act as an example for attracting private investments in the development of athletes.
\end{abstract}

Keywords: efficient investment management, high-class sports, investment criteria, Latvian sports, private investments, sports development, sports funding, sports system mass.

\section{Introduction}

Latvian sports authorities are the main organisers and maintainers of the sports life in Latvia. However, they are not able to successfully provide equally good support to all athletes who need it. Some gaps can be observed in the distribution of funding, which may affect the quality of high-achievement sports in the country.

High-achievement sports in Latvia can be divided into individual and team sports, which might make it easier to demonstrate the shortcomings of the state funding for equal development of athletes. Latvia has created a quality system for the support of Olympic individual sports through the Latvian Olympic Team. The Latvian Olympic Team provides great support to the individual athletes of Olympic sports and sports involving small teams, such as bobsleigh, luge, beach 
volleyball and the like. State authorities provide funding to these, so that athletes can be successful in raising their individual mastery levels and receive the best possible instruction, equipment, medicine and training infrastructure on a high level during the entire season. At the same time, Latvia offers neither state, nor municipal funding, which would provide systematic support for highachievement team sport athletes to build their individual capacity. There are some youth academies under a few sports clubs, but it must be admitted that their existence is merely formal, and currently there are no world-class athletes prepared by these academies. Another thing to mention is the fact that the majority of team sports clubs are funded through private sponsorship and donations.

Taking into account the objective constraints of the state budget, it is impossible to expect state funding for special youth high-achievement sports development programmes in order to produce world-class professionals in adult sports. This is the main reason why Latvian youth sports teams enjoy brilliant success until the athletes turn eighteen to twenty years old, but after that, upon entering or trying to enter adult sport, the athletes' mastery starts lagging behind that of other athletes, although at eighteen years old they were better.

World experience shows that such shortages in public funding can be successfully filled with private funding. This is usually done within team sports club youth academies, while sports management companies usually invest in tennis, golf, auto racing, or football. These companies use investment agreements and hope to recover the invested funds from professional contracts of athletes. In Latvia, also, private investment is currently the only way to ensure systematic preparation of high-achievement athletes in football, ice hockey, basketball and tennis. In Latvia this is done in the form of social support. World experience shows that direct investments in young athletes and proper management thereof can provide investors with positive return on their investments, as well as ensure enhanced overall mastery of athletes to promote the development of sports in the country as a whole.

The issue which has been reviewed in this article is related to the lack of funding and professional career support needed for young Latvian athletes, and the one-sided support from Latvian sports supporters unable to attract investors, who would be willing to make large investments. According to the hypothesis of the study, by investing private financial resources to ensure high-achievement sports conditions for individual Latvian athletes in certain sports from the age of 14 and ensuring adequate investment management, it is possible to achieve a positive return on investment. The goal of the study is to show the importance of private investments in Latvian sports, the opportunities to address current issues related to the development of youth sports and the entire sports industry by attracting private investors, develop innovative methodologies for private 
investment management in sports, while at the same time ensuring a positive investment balance of the investor and high achievement in sports.

To achieve this goal, the following tasks have been defined:

- Examine public investments in sports;

- Identify gaps in the public funding;

- Develop a solution to the funding gaps;

- Develop innovative methodologies for a more efficient investment management in Latvian sports;

- Check the efficiency of these methodologies.

The investment management processes and the general management processes are widely described in the literature throughout the world. John Maynard Keynes was one of the first to define investments in his book "General Theory of Employment, Interest, and Money" (Keynes, 1997). Obviously, the investment processes and management have been covered in countless works. On the other hand, sports investment management and sports management in general has not been a subject of much scientific research. As the sports industry realises the importance of successful sports management, the development of a successful sports management strategy is highlighted increasingly often. 'Principles and Practice of Sport Management' (Masteralexs \& Barr, 2011) are being defined and established more widely. Descriptions of 'Sports Management and Administration' and 'Financial Management in the Sport Industry' have been issued (Brown, 2010). Although there is a wide spectrum of research and descriptions on sports investment management processes and investment management to increase the mastery of athletes in the world, after analysing the available information in major scientific databases, it may be concluded that the investment management for increasing the mastery of athletes has not been previously described or studied scientifically (Foster et al., 2005).

\section{Data and methodology}

A. Analysed indicators.

The paper analyses indicators that affect the allocation of public funds in the sports sector, as well as the statistical indicators on youth sports system mass and the availability of sports infrastructure necessary to define the investment objects.

1. Sports industry structure of the Ministry of Education and Science.

2. State budget for 2015 .

3. Student statistics of professional sport education institutions.

4. Sports facilities.

5. Present value of the experimental company at the end of period.

B. Data set. 
The study used publicly available data from the database of the Central Statistical Bureau of Latvia, information provided by the Latvian Olympic Unit, information available on the website of the Latvian Ministry of Education and Science, database of the Sports Facilities' register, as well as unpublished data from the Ministry of Education and Science on the number of students and rates at professional sports education institutions. Analysed was data for the year 2015. Also, the financial indicators of the experimental company engaged in the management of private investments in Latvian athletes were used.

C. Methods.

The descriptive statistical method and content analysis were used to assess shortcomings in the allocation of finances in the Latvian sports sector. By analysing data on sports funding in Latvia and especially the funding to increase individual mastery of athletes, conclusions were reached on the shortcomings in the promotion of successful activities of all athletes in the country and the common flaws in the development of high-class athletes. After analysing the data on funding, an innovative methodology was developed to remedy the shortcomings of funding, and a company was established to deal with private investments in sports, in order to prove the hypothesis. (Bauer, 2007) The return on investments made by the experimental company was calculated by using the future profit calculation formula and investment return coefficient formula (University of Latvia, 2015).

\section{Results}

To show the shortcomings of state funding in the Latvian sports industry, the study investigated the state budget funds allocated to sporting bodies, and the sports industry structure as a whole. The breakdown is shown in Figure 1, providing a clear overview of how much funding has been allocated to each public institution.

It may be concluded that the main organiser of the sports life in Latvia is the Ministry of Education and Science. The Ministry of Education and Science is responsible for the allocation of funding between sporting bodies (On State Budget, 2015), and the key authority that has the greatest effect on the allocation of funding in the sports sector is the National Sports Council.

By analysing and drawing conclusions about sporting bodies, it may be concluded that almost all sports organisations are engaged in the mastery training, promotion of development and ensuring the activities of individual sports athletes. It should be noted that the state provides funding to sports federations that organise sports competitions both in team and individual sports, while the main task of the federations is to organise local championships. Also, the majority of 
these institutions have been established primarily to ensure the participation of athletes in international competitions.

The country has an efficient system of preparation of young athletes, but there is a lack of support of individual development, which is required in perhaps the most important stage of an athlete's career - the transition from youth to adult sport.

These deficiencies in the country's sports sector indicate that there is a need to attract private investor resources in the development of young athletes, especially in team sports.

Table 1 contains summary information on the most popular sports among young people in Latvia (Ministry of Education and Science) and the resources available to sports facilities (Sports Facilities Register), by type of sport. Table 1 can serve as the basis for the successful attraction of investors in different types of sports.

Table 1 The most popular types of sport among youth in Latvia and the available resources of sports facilities

\begin{tabular}{|l|c|c|}
\hline \multicolumn{1}{|c|}{ Type of sport } & $\begin{array}{c}\text { Participants in state sport } \\
\text { schools }\end{array}$ & Facilities \\
\hline Basketball & 6753 & 710 \\
\hline Volleyball & 5307 & 658 \\
\hline Football & 4646 & 591 \\
\hline Track and Field & 2902 & 425 \\
\hline Floorball & 2527 & 288 \\
\hline Handball & 1572 & 85 \\
\hline Swimming & 995 & 63 \\
\hline Ice-hockey & 916 & 54 \\
\hline Chess & 797 & 48 \\
\hline Freestyle wrestling & 712 & 31 \\
\hline Gymnastics & 655 & 27 \\
\hline Judo & 597 & 23 \\
\hline Gymnastics & 494 & 22 \\
\hline Kayak and Canoe & 433 & 8 \\
\hline
\end{tabular}

After analysing the data in Table 1 on the most popular sports among young people in Latvia, it may be concluded that the easiest would be to attract investors for the types of sport such as basketball, football, ice-hockey, and maybe also volleyball and handball. Although relatively few young people engage in icehockey, it is still a likely investment object, because Latvia has strong ice-hockey traditions and probably the most professional hockey players per number of youth engaged in this sport, which might be an important aspect for potential investors (Ministry of Education and Science; Central Statistical Bureau). 
Private investors must be able to cooperate with the state, thus developing a successfully functioning high-class athlete preparation centre, as depicted in Figure 1.
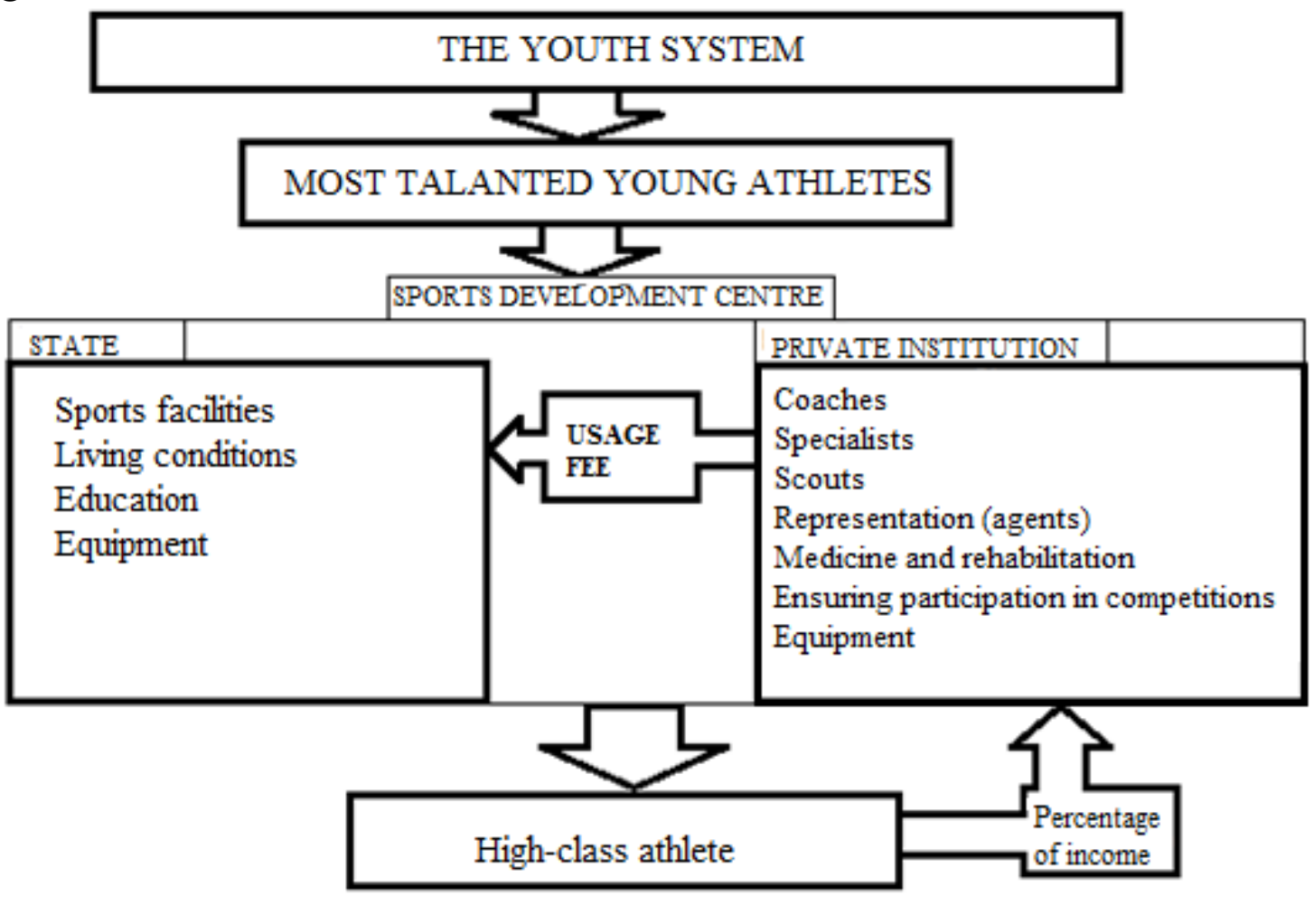

Figure 1 High-achievement sports development centre operation model

In order for the cooperation to run smoothly, state institutions must provide sports infrastructure, while private investors provide many components related to athletes' career development, which will help ensure a successful development of team sports in the country as a whole.

To demonstrate the efficiency of the innovative method in furthering the achievements of athletes, an experiment was carried out, in which a company was established engaged in the preparation of athletes for professional sports. Basketball was selected as the focus, because it is the most popular sport among young people in the country, and the Latvian Basketball League has the most professional athletes from all sports leagues in the country. The company operated in accordance with the diagram depicted in Figure 1 and provided all liabilities pertaining to the private partner as described in the diagram, thus maximising the career opportunities of athletes and facilitating their transition from youth to adult sport (Latvian Basketball Association; Central Statistical Bureau). Table 2 shows the company's performance over the years. The table also shows the company's ability to function and operate continuously, as well as investment project and management performance indicators and their development. 
Table 2 Profit/loss of BAA Riga Ltd, per year, EUR

\begin{tabular}{|l|l|}
\hline Year & Profit / Loss \\
\hline 2008 & $(-1,917)$ \\
\hline 2009 & $(-5,867)$ \\
\hline 2010 & $(-3,024)$ \\
\hline 2011 & 16,433 \\
\hline 2012 & $3,939.80$ \\
\hline 2013 & 6,958 \\
\hline 2014 & 19,808 \\
\hline
\end{tabular}

In order to properly evaluate the success of the experiment and validate the hypothesis, calculations were made to estimate the future value of resources invested and the return on investment coefficient. The return on investment was calculated as 2.12, from which it could be concluded that the investment project works and is able to sustain its future operation, which proves that it is possible to attract private investments in the development of athletes in Latvia and ensure their management.

\section{Discussion}

It is also important to understand that in most team sports adult athletes engage in sports for a certain fee and are able to sustain themselves and improve their mastery. Therefore, it is essential for the state to support the many individual types of sport, where athletes are not able to fund their own training from their professional sports activities. Although many team sport athletes are able to fund their own development, the vast majority of athletes fail to build a professional athlete's career due to the difficult transition from youth to adult sport.

Funds for training are provided only from the Latvian Olympic Unit, and these funds are allocated according to the criteria for individual sports. Although Latvian team sport athletes achieve equally good results, it is virtually impossible for them to receive state funding for training. It goes without saying that the state does not have enough resources to support athletes of all types of team sports (Latvian Olympic Unit).

The main drawback of state funding is the insufficient funding of team sport athletes to prepare them for adult sport, which can become an obstacle in the careers of many athletes. When making conclusions on the practice and the development of athletes in other countries, one can develop a successful model where private investors support young athletes. The country has a successfully functioning selection process of athletes for the allocation of funding to individual sport athletes. A similar system with strict selection criteria can also be used by 
private investors in order to increase effective operation of their investment projects and evaluate investment objects.

It is important to note that private investors and the state share the risks in case of a failed athlete's career, which might allow to maximise the return from a youth system in the country, and to raise high-achievement sport results in the country as a whole, and in particular in those sports that require large investments in early stages of athletes' careers.

In order to successfully attract private investors in the development of athletes, it is necessary to identify the types of sports that have the required base of young athletes and who can provide the investor with sufficient return on investment for the management project to be profitable and sustainable in the long term. Another thing to be understood is that it is virtually impossible for private investors to create new sports facilities for the development of athletes, which are vital for the development of young athletes.

Looking at the company's operating results, it can be concluded that, as in other investment management projects, the beginning is associated with selecting the right investment and the right investment objects, while further steps are related to successful product development and promotion. For an investment project to function properly, a legal relationship was established between the investor and the athlete, so that in case of a successful activity of the investor, the athlete would pay back the support provided in his/her career development.

The analysis showed that private investors are much better equipped to prepare athletes for adult team sports. One of the main factors is certainly the fact that private investors have a personal interest in raising the mastery of the athlete. Also, private investors have much better opportunities of attracting foreign specialists to raise the mastery of young athletes.

The weakest link of private investments in sports is the necessary sports infrastructure to ensure one's own operations, which requires large investments. That is why public and private investors need to build successful partnership from which both parties will benefit.

\section{Conclusion}

1. The state provides funding to ensure sports activities in the country. The main organ for the organisation of the national sports life is the Ministry of Education and Science. The institution, which influences the distribution of sports funding the most, is the National Sports Council. Several state institutions provide development of individual athletes.

2. The main problem of state funding is the inability to ensure sufficient funds for the individual development of team sports athletes in accordance with high-achievement sport requirements. 
3. The problem described above can be solved by attracting private investments to ensure efficient development of athletes, where the return will be produced by direct payments of the athletes upon reaching a certain level of mastery.

4. After verifying the efficiency of the method-i.e., the development of sports investment management centres and companies - by using the experimental method, as well as analysing the financial indicators of the established company, it may be concluded that the method works in the development of athletes and that it is a successful investment opportunity.

The study has lead to the conclusion that, in order to improve the efficiency of investment management methods, research should be performed on topics such as the development of criteria for a successful selection of young athletes, factors contributing to the development of athletes, circumstances promoting the cooperation between state institutions and private entrepreneurs, legal and psychological aspects of the cooperation between investors and athletes, and the connection between risk capital investment management and investments in athletes. Further studies must be conducted on the role of private investment management in the development of athletes.

\section{References}

Bauer, M. W. (2007). Content Analysis. An Introduction to its Methodology, Retrieved from http://onlinelibrary.wiley.com/doi/10.1111/j.1468-4446.2007.00153_10.x/abstract

Brown, M. (2010). Financial Management in the Sport Industry Phoenix, Holcomb Hathaway Central Statistics Bureau Retrieved from: http://data.csb.gov.lv/pxweb/lv/Sociala/ Sociala_ikgad_veseliba/VA0221.px/table/tableViewLayout1/?rxid=cdcb978c-22b0416a-aacc-aa650d $3 \mathrm{e} 2 \mathrm{ce} 0$ - viewed on 26 December 2015

Foster, G., Greyser, S. A., \& Walsh, B. (2005). The business of sports: Cases and text on strategy and management. Belmont, CA: Thompson South-Western.

Keynes, J.M. (1997). The General Theory of Employment, Interest, and Money. New York: Prometheus Books.

Latvian Basketball Union. Retrieved from: www.basket.lv

Latvian Olympic Unit (2015.23.12). Latvijas Olimpiskās vienības finansējums, Retrieved from: http://www.lov.lv - viewed on 23 December 2015

Masteralexis, L., Barr, C., \& Hums, M. (2011). Principles and practice of sport management. Jones \& Bartlett Publishers.

Ministry of Education and Science. (2012). Structure of Sport Industry. Retrieved from: http://www.izm.gov.lv/lv/sports/sporta-nozares-struktura - viewed on 2015.20.12.

Parliament of Latvia. (2014). On the State Budget 2015. Retrieved from: http://www.fm.gov.lv/lv/sadalas/valsts_budzets/2015_gada_budzets_/

Register of Latvian sport facilities (2015.20.12). Retrieved from - $\mathrm{http}$ ://sportaregistrs.lv/ -

Stewart, B. (2014). Sport Funding and Finance: Second edition. New York: Routledge.

University of Latvia. (2015.08.12.). Data acquisition methods. Retrieved from: http://estudijas.lu.lv/pluginfile.php/91578/mod_resource/content/0/Jaunais_saturs/1/Dat u_iegusanas_metodes_Kvalitativie.pdf

Watt, D. C. (2003). Sports management and administration. Psychology Press. 